\title{
Från materialitet till sociomaterialitet
}

\author{
Lärande i en designad värld
}

\author{
Roger Säljö
}

Våra sätt att tala om kunskaper och färdigheter präglas av perspektiv och distinktioner som formulerades redan under Antiken, för mer än 2000 år sedan. Här etablerades motsättningar, dualismer, som den mellan teori och praktik, kropp och själ, och tanke och handling, som skulle få stor betydelse inte bara för vår syn på kunskap, utan också för hur vi uppfattar sociala roller. Genom dessa distinktioner etablerades en skillnad mellan intellektets/tänkandets aktiviteter och kroppens/ handens, som än idag reproduceras och som har konsekvenser. Vi talar exempelvis om teoretiska ämnen och praktisk/estetiska ämnen $i$ skolan, och vissa yrken ses som praktiska och andra som teoretiska. Vetenskapliga discipliner formerades också med dessa dualismer som bakgrund, vissa handlar om kroppen, andra om psyket/själen/intellektet. Vi fick en uppdelning, compartmentalization som man säger på engelska, där en helhet - en människa-delades upp i delar som studerades var för sig (intellekt, minne, hjärna, styrka, hälsa m fl). Tanken är att kunskaper från dessa områden så småningom om ska kunna syntetiseras så att vi ska kunna uttala oss om helheten. Men detta är inte helt enkelt. Utgångspunkten för detta kapitel är att materialitet och interaktion med materiella föremål är grundläggande för lärande och utveckling hos individer, $i$ institutioner och på samhällsnivå. Det är när våra insikter omsätts $i$ materialitet, som de befästs och kan användas. Det är också genom interaktion med en fysisk och sociomateriell omvärld som vi lär och utvecklas. I kapitlet ges exempel på hur artefakter utvecklats och hur dessa samtidigt är manifestationer av kunskaper och tillika utgör en bas för utveckling av "praktiska” kunskaper. Vi kan och lär genom att hantera artefakter och detta gäller alla slags kunskaper: språkliga, intellektuella, estetiska och sådana som innebär att vi hanterar och modifierar vår fysiska omvärld. Design är en grundläggande form av mänsklig kunskapsutveckling och här kan inte tanke och kropp skiljas åt.

\section{Inledning}

Våra sätt att tala om kunskaper och färdigheter präglas av perspektiv och distinktioner som formulerades redan för mer än 2000 år sedan i det antika Grekland. Här etablerades motsättningar, dualismer, mellan teori och praktik, kropp och själ, språk och verklighet, och tanke och handling (Danziger, 1997). Dessa motsättningar skulle få stor betydelse i det västerländska samhället och 
inte bara för vår syn på kunskap och mänskliga förmågor, utan också för hur vi uppfattar sjukdom och hälsa, sociala roller, yrken och aktiviteter. Genom dessa distinktioner skapades en skillnad mellan intellektets/tänkandets aktiviteter och kroppens/handens dito, som än idag reproduceras och som har konsekvenser. Vi talar exempelvis om teoretiska ämnen och praktisk/estetiska ämnen i skolan, och vissa yrken ses som praktiska och andra som teoretiska. En, av många, konsekvenser av detta sätt att tala och tänka är också att den som inte "klarar av teori", bör söka sig till ett "praktiskt" yrke. En ytterligare indikation på denna djupt rotade föreställning är att intellektet kan tränas för sig och att estetiska, manuella och kroppsliga aktiviteter är något annat; "övning" eller "tillämpning" som bekräftar vad man lärt sig, men som inte bidrar till kunskapsutveckling i den mening som "teori” gör.

Utgångspunkten för detta kapitel är att materialitet och interaktion med föremål är grundläggande för lärande och utveckling hos individer, för institutioner och för uppbyggnad och bevarande av kollektiva erfarenheter, både "teoretiska" och "praktiska." Det är när våra insikter omsätts i materialitet, som de befästs, kan användas och blir tillgängliga i samhället för breda grupper; de blir delar av och ingångar i vårt "kulturella minne" som Donald (2018) formulerar det. Det är också i stor utsträckning genom interaktion med en sociomateriell omvärld som vi lär och utvecklas. Kraven på utveckling uppkommer eftersom vårt vardagsliv blir alltmer komplext och numera utgörs av texter, bilar, datorer, massmedier, robotgräsklippare, och en oändlig mängd mer eller mindre tillförlitliga artefakter som kräver olika slags kunskaper och färdigheter när de ska användas. I kapitlet ges exempel på hur artefakter (tillverkade föremål) utvecklats och hur dessa samtidigt är manifestationer av kunskaper och tillika utgör en bas för utveckling av "praktiska" och "teoretiska" kunskaper. Vi kan och lär genom att hantera artefakter och teknologier (som byggs upp av artefakter), och detta gäller alla slags kunskaper: språkliga, intellektuella och estetiska. Bruk och skapande av artefakter är grundläggande sammanhang för mänsklig kunskapsutveckling och här kan tanke och materialitet inte skiljas åt.

\section{Sociomaterialitet och lärande: en historisk utgångspunkt}

För att förstå den roll som materialitet spelar för våra kunskaper och färdigheter, måste man ha ett långt historiskt perspektiv. Alla varelser lever i en materiell värld som ger förutsättningar för beteenden och livsformer, och som samtidigt sätter gränser för vad de kan göra. På en allmän nivå delar vi dessa omständigheter med andra levande varelser. För människan, och för våra föregångare i släktet Homo, gäller dock att vi i betydande utsträckning ingripit i och omvandlat den värld vi lever i. Våra omgivningar är till största delen designade och innehåller artefakter, teknologier och sociala arrangemang som utvecklats av människor för specifika syften. Vi bor i hus med spisar, kylskåp 
och annan utrustning och vi förflyttar oss med diverse olika färdmedel. Även det som vi kanske uppfattar som naturligt, en skog eller en äng, kan vid närmare betraktande ofta visa sig ha något att göra med mänskliga avsikter och ansträngningar. Skogen kan vara planterad, träden eller buskarna ett resultat av växtförädling och ängen kan vara en rest av tidigare odlingar som lagts i träda. Artefakter och teknologier är på ett något motsägelsefullt sätt den naturliga omgivningen för människor (Ihde, 1990). Vi gör våra erfarenheter i samverkan med artefakter och teknologier.

Artefakter uppkommer ur processer som vi numera kallar design och de är ett uttryck för vår förmåga att uttrycka, utveckla och $\mathrm{i}$ bokstavlig mening förtingliga kunskaper. Vi kan ta ett material, lera eller trä, och göra ett objekt i form av en skål eller sked. Dessa designade föremål ändrar därefter våra sätt att utföra handlingar i vardagliga sammanhang. För att transformera ett naturligt material till en artefakt med specifika egenskaper krävs erfarenheter och kunskaper. Vi måste veta något om material och deras användbarhet för specifika syften, och vi måste också ha en bild av vilken funktion en artefakt som en skål eller en sked ska fylla. Reflektion, analys och "teori" är därför nödvändiga inslag i skapande av artefakter. Design är en grundläggande beståndsdel i lärande på kollektiv och individuell nivå, och lärande är i många fall idag en fråga om att kunna designa (Kress \& Selander, 2010).

I förbigående är det intressant att notera att aktiviteter som att använda eller till och med tillverka artefakter förvisso inte är helt unikt för människor. Användning av redskap förekommer hos ganska många djurarter, exempelvis fåglar, uttrar, delfiner och till och med insekter. Tillverkning av redskap är inte lika vanligt. Det är framför allt primater som i naturliga omgivningar påvisats tillverka redskap, även om det finns andra exempel. Schimpanser kan använda stickor för att ta sig in i termitstackar och dessutom kan de forma stickan så att den passar för syftet (Whiten et al., 1999). I några uppmärksammade studier har man också visat att schimpanser i en speciell miljö tillverkar "spjut" för att användas vid "jakt" (Pruetz et al., 2015). Dessa former av redskapsbruk utgör anpassningar till lokala förutsättningar för att komma åt föda eller hävda sig, och de ger djur en större variation i sina beteenden som i sin tur ökar möjligheterna att överleva. Redskap av detta slag innebär dock inte att man omvandlar sin livsvärld i den mer genomgripande mening som vi gör. Bruket av artefakter når helt andra nivåer hos människor och ingen annan varelse är på gott och ont så beroende av teknologier för sitt dagliga liv som vi. 
I det perspektiv jag här antytt, gör vi våra erfarenheter och utvecklas i en sociomateriell omvärld. Yrkesutövare som sjuksköterskor, snickare, revisorer och andra förlitar sig på och bygger upp sin skicklighet genom en ökande grad av förtrogenhet med redskap av olika slag: röntgenapparater, ritningar, och bokföringsprogram. Lärare lär sig använda både traditionella teknologier (böcker, linjaler) och i våra dagar digitala redskap (datorer, whiteboardtavlor) för pedagogiska syften. Ett mycket intressant och nutida exempel på detta erfarande i samspel med teknologier är små barn, så unga som under ett år, som växer upp och utvecklas i en värld av digitala plattor, appar och som spenderar alltmer tid i online aktiviteter (Statens medieråd, 2019). I sina alltmer digitala liv gör barn (och vuxna) en mängd sociala, intellektuella och materiella erfarenheter som inte tidigare generationer har gjort och för att kunna delta i sådana aktiviteter, utvecklar de kunskaper och färdigheter i att använda digitala redskap.

En intressant fråga är om denna sociomateriella utveckling har några konsekvenser för hur människor lär och hur man kan organisera lärande? I ett dualistiskt perspektiv på människors förmågor uppfattar vi att tänkande är en aktivitet som är förlagd till hjärnan. Detta följer ur den åtskillnad mellan det materiella och det tankemässiga som jag nämnde inledningsvis och vars rötter finns $\mathrm{i}$ Antiken. I hjärnan finns ett antal centra för språk, hörsel, minne och andra funktioner, och kognition beskrivs som lokaliserad i en konkret mening. Av denna metaforik följer också antagandet att lärande innebär att "ta in" information via våra sinnen för att "bearbeta" den och sedan "lagra" den i våra minnessystem. Denna mekanistiska metaforik utövar ett starkt inflytande i många sammanhang, både $\mathrm{i}$ forskning och $\mathrm{i}$ vardagliga resonemang (Säljö, 2015). Detta gäller särskilt tydligt i vår tid som utmärks av tendenser till en stark biologisk reduktionism av lärande och kognition som ibland beskrivs som "brainism" eller "neurocentrism" (Satel \& Lilienfield, 2013). Den mekanistiska metaforiken lämnar inget utrymme för meningsskapande eller för att inkludera de sociomateriella redskapens roll i vårt tänkande/kunnande/handlande. Det är som om vår materiella kultur och dess utveckling saknar betydelse för vårt tänkande eller våra möjligheter att förstå och ingripa i världen.

Mot denna bild kan man ställa idén om att vårt tänkande också är kroppsligt, embodied (Varela, Thompson, \& Rosch, 1991), och gestaltas genom samspelet mellan våra sinnen, kroppsliga erfarenheter och vår förmåga att tänka, abstrahera och göra erfarenheter i samspel med andra människor och sociomateriella objekt. Våra mentala fömågor är således inte inneslutna i sig själva utan vända utåt, mot världen. Detta perspektiv innebär att vårt tänkande och våra kunskaper är "extended" och "distributed" (Hutchins, 1995; Malafouris, 2013) mellan människor och mellan människor och artefakter. Det finns ingen tydlig gräns mellan mina kognitiva förmågor och bruket av redskap, de utgör en odelbar 
helhet i sociala handlingar. Jag söker information och gör mina bankärenden med mobilen eller datorn, och denna helhet är grunden för vad jag kan åstadkomma. En pilot interagerar med en rad instrument som ger data för hur hon ska agera, och i denna aktivitet går det inte att skilja tänkande från dess samspel med instrumenteringen (Hutchins, 1995). Som Bateson (1972) uttrycker det i sin berömda sentens: "the mental characteristics of the system are immanent, not in some part, but in the system as a whole" (s. 316). Människor som samarbetar med artefakter agerar således i en "helhet" där man inte kan separera hjärnan eller vårt tänkande från de andra delarna av den "helhet" vi handlar i.

\section{Artefakter, teknologier och kunskapande}

Att förstå kunskapande och lärande innebär således att vi måste ställa frågor om hur artefakter och teknologier integreras med våra sätt att tänka och utföra aktiviteter, och hur detta i sin tur har utvecklat våra kunskaper och förmågor att handla och förstå. Hur kommer det sig att jag kan "minnas" hundratals telefonnummer? De finns inte i mitt eget minne, utan i mitt samspel med de medierande redskap som mobilen eller anteckningsboken utgör (Vygotsky, 1986). Minnande är ett tydligt exempel på en redskapsberoende sociomateriell praktik (Säljö, 2011). Utan externa redskap är vår förmåga tämligen begränsad, med tillgång till artefakter som texter, databaser och annat, är den praktiskt taget obegränsad. På samma sätt är det med andra artefakter; med ett mikroskop eller ett teleskop kan vi observera företeelser som är osynliga för ögat och vi kan lära om molekyler och galaxer.

Alla artefakter har en sociogenes, en utvecklingshistoria, och denna historia säger oss också mycket om hur vi, våra förmågor och aktiviteter utvecklats. Att studera artefakters uppkomst och utveckling är att studera vår egen kognitiva utveckling. De äldsta fynden av artefakter går mycket långt tillbaka i tiden, mer än 3,3 miljoner år (Figur 1) (Harmand et al., 2015). Det rör sig om stenverktyg som användes för att skära, krossa nötter och liknande, och som framställdes genom "knapping", dvs. man slog med en sten mot en annan sten för att få fram ett objekt med vissa egenskaper (figur 1). Detta är de tidigaste exemplen på design av artefakter och markerar en övergång från att använda en sten man hittar i naturen till att forma ett objekt, en övergång från en opportunistisk användning av det som råkade finnas omkring gruppen till skapandet av artefakter, dvs redskap med specifika egenskaper. Genom användning av sådana stenskärvor utökas möjligheterna att skära i kött, att ta loss djurhudar från döda bytesdjur och att karva i trä. Dessa första artefakter är föregångare till den klassiska handyxan som användes under mycket lång tid, nästan två miljoner år (Diez-Martín et al, , 2015). Gränserna för våra förfäders förmåga att ingripa i 
naturen försköts; det som inte var möjligt eller svårt att göra, blev en vardaglig del av en sociomateriellt mer differentierad kultur.

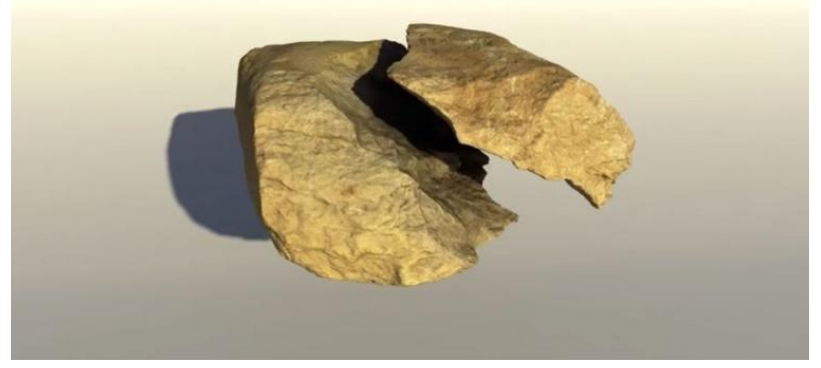

Figur 1. Ett stenredskap ca. 3,3 miljoner gammalt från Kenya (Harmand et al., 2015)

Det uppkommer så småningom en sociomateriell evolution genom att tillverkningstekniken förädlas och man tillverkar artefakter som spjut- och pilspetsar. I sådana utvecklingsprocesser utgör den befintliga artefakten och tekniken utgångspunkten både för nya generationers bruk av redskapen och för en vidare utveckling av dem. I denna utvecklingsgång utgör den forntida handyxan en föregångare till moderna hammare av olika material och med olika design, och till och med den moderna spikpistolen och andra redskap finns i denna evolutionära kedja.

Som en följd av materiell innovation skapas också sociala praktiker som blir mer komplexa just genom att man utnyttjar artefakterna. Jakt med spjut eller pilbåge förutsätter ett lärande genom deltagande (Lave \& Wenger, 1991), där nybörjaren får insikter i hur man ska bete sig när man jagar och vad redskapet gör möjligt i olika konkreta situationer. Man lär sig inte bara hur redskapet ska hanteras $\mathrm{i}$ en direkt fysisk mening, man lär sig komplicerade mönster för hur man deltar i jakt i grupp och vad man bör och inte bör göra för att jakten ska bli framgångsrik. Samtidigt finns då möjligheter att göra observationer om vad som skulle kunna förbättras i vapnets design och uppbyggnad. Innovationer bygger på att man kan definiera någon brist $\mathrm{i}$ befintlig design där man noterar att det etablerade redskapet inte räcker till. Oftast har sådana utvecklingsförlopp gått i tämligen små steg i historien när nya erfarenheter inkorporerats i redskapet.

Utvecklingen av den materiella kulturen började således långt innan vår art Homo Sapiens - uppträdde här på jorden, omkring tre miljoner år tidigare, ett hisnande tidsspann. Hur och varför våra förfäder i grenen Homo började utveckla redskap är inte lätt att uttala sig om och även om arkeologer hittar allt 
fler och allt äldre redskap, blir alla sådana diskussioner något osäkra. Vi måste försöka rekonstruera den process som ledde fram till att artefakter utvecklades genom att studera deras design och användning. Även om det kan vara svårt att nå visshet, är sådana diskussioner ändå principiellt intressanta, eftersom evolutionen av materiell kultur säger mycket om vilka vi är och om våra förmågor.

Om man utgår från tanken om kunskaper som "embodied", och som beroende av en sociomateriell utveckling, blir slutsatsen att våra kognitiva och språkliga förmågor har vuxit fram i ett ömsesidigt samspel med artefakter och teknologier. Dom har vuxit fram genom "material engagement" (Malafouris, 2013). Vi har utvecklat vår förmåga att använda, analysera och tillverka artefakter, och att arrangera dem $\mathrm{i}$ allt mer komplexa teknologier, och det är detta som i betydande grad utgör grunden för våra kunskaper och våra analytiska, språkliga och estetiska förmågor. Den viktiga insikten här är alltså att materialitet och kunskapande går hand i hand och utgör varandras förutsättningar; när komplexa och specialiserade artefakter introduceras och används, uppkommer behov av kunskapsutveckling hos individer.

Det är också rimligt att anta att behovet av någon form av undervisning växer fram när artefakter används och arbetsformer och sociala mönster blir mer komplexa (Gärdenfors \& Högberg, 2017). Att tillverka och använda redskap förutsätter observation och imitation men också någon form av instruktion om hur man ska bete sig när man formar och använder redskapet. Eftersom den materiella kulturen började utvecklas långt innan språklig kommunikation uppstod, måste gester och kroppslig kommunikation använts för att introducera nybörjare i aktiviteter som jakt, fiske, matlagning och annat.

\section{Artefakter för hand och tanke}

De artefakter som inledde denna långa utveckling mot vad vi ser omkring oss idag kallar filosofen Wartofsky (1979) "primära artefakter." Det är redskap som yxor, hjulet och pilbågen som har egenskaper som tar oss bortom våra naturgivna fysiska förmågor. Det uppstår med andra ord en koppling mellan människa och artefakt som tillsammans kan åstadkomma något som ingen av dem kan var för sig. Och våra egna förmågor utvecklas i samspel med sådana redskap, vi blir skickliga i redskapsmedierade aktiviteter som att cykla, fälla träd eller spika i en spik.

Vi utvecklas också genom tillgång till vad Wartofsky kallar "sekundära artefakter" i form av instruktioner, förklaringar och bilder, ritningar, mönster och texter som stödjer oss i hur vi ska hantera primära artefakter. Sekundära artefakter utvecklas i spåren av de primära. Den elev som i slöjdundervisningen i skolan i dag ska lära sig använda en symaskin eller en hyvel (Johansson, 2002, s. 93ff) befinner sig i en situation där man utvecklar komplexa kunskaper som 
bygger på att man förmår samordna instruktioner och ritningar/mönster (sekundära artefakter) med material för att skapa en primär artefakt (en kudde, en skål eller något annat) med vissa egenskaper. En viktig beståndsdel i lärande i sådana situationer finns i att försöka överbrygga det "mellanrum" som alltid finns mellan primära och sekundära artefakter. Vi vägleds av instruktioner i komplexa praktiker, men att följa mönster eller ritningar kräver analytisk förmåga och vanligtvis också andra förmågor som att kunna läsa och tyda bilder.

Behovet av instruktion och undervisning triggas således också genom utveckling och användning av primära artefakter, och instruktioner är en viktig form av sekundära artefakter. I spåren av denna utveckling växer kommunikativa genrer fram som har som syfte att kommunicera kunskaper om hur artefakter ska användas. Vi utför inte enbart fysiska handlingar, vi pratar också om vad vi gör, om förutsättningar och villkor för hur en artefakt ska formas och hur den kan användas. Erfarna personer delar med sig av sina insikter och förmedlar dem genom tal, skrift och annan kommunikation. I pedagogiska situationer inom skolans ram blir poängen inte enbart hanterandet av artefakten, utan att man lär sig något om material, hållbarhet, design och annat som är relevant i relation till formande och användning av en viss artefakt.

I vår tid kan detta slags kommunikation iakttas i klassrum där artefakter har en tydlig roll. I excerptet nedan ges ett exempel på en serie sådana instruktioner där en slöjdlärare bäddar in förståelsen av hur en glasskärare fungerar i olika sammanhang.

Excerpt 1. (hämtat från Johansson, 2002, s. 184, förkortad version)

\begin{tabular}{|l|l|l|l|}
\hline Tur & $\begin{array}{l}\text { Lärarens } \\
\text { aktiviteter }\end{array}$ & Lärarens språkliga aktiviteter & Elevers aktiviteter \\
\hline $23: 2$ & $\begin{array}{l}\text { Håller upp glas- } \\
\text { skäraren. Pekar med } \\
\text { pekfingret på toppen } \\
\text { av glasskäraren. }\end{array}$ & $\begin{array}{l}\text { Man har en glas-skärare. I mitt fall } \\
\text { här så har jag köpt en med } \\
\text { hårdmetallrulle här uppe, det finns } \\
\text { även med diamant där. En sådan här } \\
\text { hårdmetallrulle kostar 15-20 spänn, } \\
\text { en med diamant kostar 115-120. } \\
\text { Diamant använder yrkesmännen } \\
\text { alltid. }\end{array}$ & $\begin{array}{l}\text { Eleverna tittar på } \\
\text { glasskäraren. Står helt } \\
\text { tysta och betraktar. }\end{array}$ \\
\hline
\end{tabular}


Slöjdkunnande i förändring - Slöjdkunnande: utmaningar och återupptäckter

\begin{tabular}{|c|c|c|c|}
\hline $23: 3$ & $\begin{array}{l}\text { Håller upp } \\
\text { glasskäraren }\end{array}$ & $\begin{array}{l}\text { För min del som skär ganska lite } \\
\text { glas så räcker det med hårdmetall. } \\
(\ldots .)\end{array}$ & $\begin{array}{l}\text { Eleverna tittar på } \\
\text { glasskäraren. Står helt } \\
\text { tysta och betraktar. }\end{array}$ \\
\hline $23: 4$ & $\begin{array}{l}\text { Håller kvar } \\
\text { glasskäraren i } \\
\text { handen och tar upp } \\
\text { en tuschpenna. } \\
\text { Lägger ned } \\
\text { glasskäraren. Tar } \\
\text { upp linjal och } \\
\text { spegelglasbit. }\end{array}$ & $\begin{array}{l}\text { Man skär inte igenom glaset utan } \\
\text { man gör en repa så att den ... att det } \\
\text { går att bryta av, det beror på. En del } \\
\text { tror att man kan göra som på fiction, } \\
\text { att man skär liksom skär runt runt } \\
\text {... så plockar man ut glaset. } \\
\text { Men det går ut på att man knäcker } \\
\text { loss det. (...) }\end{array}$ & $\begin{array}{l}\text { Eleverna tittar på } \\
\text { glasskäraren. Står helt } \\
\text { tysta och betraktar. } \\
\text { Några elever tittar och } \\
\text { har öppen mun. Lutar } \\
\text { sig mer framåt. }\end{array}$ \\
\hline $23: 5$ & $\begin{array}{l}\text { Lägger linjalen } \\
\text { ovanpå spegelglaset. } \\
\text { Ritar märken med } \\
\text { tuschpennan på } \\
\text { spegelglaset. }\end{array}$ & $\begin{array}{l}\text { Man mäter från kanten hur långt } \\
\text { man ska gå. } \\
\text {.. } \\
\text { Man kan tänka sig tre centimeter. } \\
\text { Så märker jag upp det naturligtvis, } \\
\text { på det sättet. }\end{array}$ & $\begin{array}{l}\text { Eleverna tittar på } \\
\text { glasskäraren. Står helt } \\
\text { tysta och betraktar. } \\
\text { Några elever tittar och } \\
\text { har öppen mun. }\end{array}$ \\
\hline
\end{tabular}

Denna presentation av läraren syftar till att klargöra hur man skär i glas, en teknik som eleverna uppenbarligen inte har någon erfarenhet av. Innan vi kommer in i samtalet, har man diskuterat en situation där denna fråga blir aktuell, nämligen när någon ska göra en ljuslykta i slöjden, dvs. samtalet ovan sker i ett sammanhang av design. Vad läraren gör i detta utdrag när eleverna står framför artefakterna - glasskäraren och glaset - är att situera det man ska göra i flera olika sammanhang samtidigt. Dels förklarar läraren att det finns olika slags skärare (hårdmetall vs. diamant), dels kommenteras att det är skillnad på vad hobbyanvändare och yrkesmän behöver. Skillnaderna i kostnader för de båda varianterna klargörs likaså. Därefter kommer läraren in på handhavandet och förklarar hur man skär i glas och påpekar att man inte ska skära igenom glaset, utan man "gör en repa i den så att den ... att det går bryta av." Denna utsaga är ett intressant exempel på hur instruktioner medierar något som samtidigt är både generiskt och specifikt; när man skär i glas, ska man inte skära igenom (underförstått: som man gör när man skär eller sågar i andra material), utan man repar och bryter av. Sedan följer en förklaring - språklig och icke-verbal - av tekniken för redskapsanvändning: hur man mäter, håller glasskäraren och vad man ska tänka på.

Utdraget illustrerar hur artefakterna och arbetsprocesserna genererar samtal om olika aspekter av glasbearbetning. Presentationen rör teman som material och deras kvaliteter, yrkesmäns behov, kostnader, och eleverna görs delaktiga i distinktioner om hur man kan "skära", göra en "repa", hur man mäter, och vad man inte ska göra. Dessa distinktioner stöttar förståelsen av aktiviteten och gör den begriplig och lärbar för eleverna. Artefakten sätts således in i en berättelse på olika nivåer och berättelser utgör en av människans viktigaste kunskapsformer. 


\section{Sociomaterialitet och utveckling av individer och samhälle}

Ur historien kan vi se att en snabb utveckling av teknologier kommer till stånd när människor lever i nya omständigheter och utsätts för utmaningar. Exempel på sådana sociokulturella förändringar är när jordbruket uppkom, när människor blev bofasta och när mer komplexa samhällsformer som byar och städer med handel och andra aktiviteter växte fram. I alla dessa miljöer uppkom nya artefakter och teknologier som utvecklades för att stödja nya sätt att leva. Jordbruket blev navet för utveckling av en lång rad redskap för att bearbeta jorden, för att utveckla grödor och i samspel med detta växer en rad kunskaper om hur man odlar, bevattnar och planerar för framtiden (Harris, 1996). Seglingskonsten genererade efter hand teknologier som hade med navigation, båtbyggnad och segelmakeri att göra, och den vidgade också människors erfarenheter. Skrivkonsten som utvecklades i de första städerna blev utgångspunkt för en sociomateriell och intellektuell utveckling med dramatiska konsekvenser för våra förmågor att dokumentera, analysera och förstå, och för uppbyggnaden av skolor och andra institutioner där undervisning och lärande utgör huvudsaklig aktivitet (Lundgren \& Säljö, 2020).

En anledning till att artefakter och teknologier är så viktiga för lärande och kunskap är således att de är mer än fysiska objekt. Det är därför det är meningsfullt att tala om sociomaterialitet. De bär på en historia och inbjuder således till specifika sätt att agera och leva. Hammaren är formgiven så att de flesta förstår att man ska gripa tag i handtaget och tangentbordet på datorn inbjuder till vissa sätt att skriva och komponera texter. Som psykologen Michael Cole påpekar utmärks artefakter av att de både är materiella och begreppsliga (ideational). De är materiella i den mening att de har blivit "created by modifying physical material in the process of goal-directed human actions." Och de är begreppsliga, eftersom deras materiella "form has been shaped to fulfill the human intentions underpinning those earlier goals" (Cole \& Derry, 2005, s. 4). Genom att en artefakt integrerats i en verksamhet och löst ett problem för människor, finns den kvar och innehåller därmed de distinktioner och former som varit centrala. När vi använder en kratta eller en kompass utnyttjar vi de insikter som tidigare generationer gjort och som de omsatt i artefakter med specifika egenskaper.

Det är också rimligt att anta att arbete med materiellt skapande triggat våra förmågor att tänka, analysera och överväga alternativa sätt att lösa problem. Aktiviteter som design och skapande av artefakter förutsätter att man kan tänka hypotetiskt och modellera världen. För att tillverka ett föremål måste man tänka igenom vilka material som är lämpliga med avseende på olika egenskaper och på hur föremålet ska användas. Detta förutsätter både analytiska förmågor och 
fantasi, och en förmåga att förutsäga användning och en rad olika sociala processer. Kunskaper om samhället och brukarna inkorporeras således i designen.

En artefakt bär också med sig en slags läroplan, ett budskap om hur den ska användas. Delar av funktionen kan vara uppenbar genom redskapets design, som i fallet med en yxa eller spade, men andra aspekter av handhavandet kan vara mindre uppenbara (som i fallet med eleverna när de ska lära sig skära i glas). Risker och faror som kan uppstå när man använder redskap kan vara okända för den ovane användaren. För många, kanske de flesta, primära artefakter behöver vi således någon form av instruktion för att vi ska lära oss hur de ska användas. När artefakter sätts samman i komplexa teknologier får de ofta egenskaper som inte går att inse utan omfattande instruktioner. När grävandet utförs av en modern grävmaskin, eller när skogen bearbetas av en skogsmaskin, är steget till att behärska artefakterna ganska långt. Det är många aspekter av artefakten som en nybörjare måste bekanta sig med genom att ta del av undervisning, handböcker och instruktioner av handledare. I moderna artefakter är det också vanligt att en mängd av de funktioner som är inbyggda i artefakten är osynliga även om man betraktar den. De har blivit "blackboxed" som Latour (1999) uttrycker det. Vi kan hantera artefakter och teknologier som navigatorer, sökmotorer och komplexa maskiner, utan att vi förstår hur de fungerar på alla nivåer. Tekniken har dolt många processer och funktioner och det är detta som gjort dem framgångsrika som Latour uttrycker det.

\section{Materialitet och symboliska teknologier}

Genom utveckling blir således de primära artefakterna alltmer kraftfulla och därmed också komplexa i sin uppbyggnad. Det är stor skillnad mellan de kunskaper som förutsätts av någon som ror en roddbåt respektive hanterar en oljetanker på flera hundra tusen ton i ett hårt trafikerat vatten. Den som brukar jorden med hjälp av häst och plog har andra kunskaper än den som sköter moderna och komplexa jordbruksmaskiner med avancerade tekniska funktioner. Den sociotekniska evolutionen har höjt kraven på kompetenser hos brukarna inom de flesta områden och i många fall ställs det krav på överblick och mer abstrakt förståelse av arbetsformer, odlingstekniker och inte minst ekonomi.

I ett långt historiskt perspektiv har således den materiella kulturen varit avgörande för våra förmågor att tänka och lösa problem. Materialitet är en viktig aspekt av det vi kallar tänkande, som jag påpekat ovan. Vi tänker med och genom artefakter i allt fler aktiviteter. Det slags artefakter som vi kan kalla symboliska teknologier (Donald, 2010, 2018) är särskilt intressanta i detta sammanhang. De har mycket gemensamt med Wartofskys sekundära artefakter, men de är mer generella och etablerar ofta en egen värld av aktiviteter. Symboliska teknologier är artefakter "that are specifically designed to represent, communicate and store knowledge" (Donald, 2010, s. 71). Hit hör räknare, 
papper och penna, texter, kompasser, datorer, mjukvaror och mycket annat av det vi har omkring oss. Dessa artefakter ökar således våra förmågor att dokumentera, bevara och bearbeta information, i analogi med hur primära artefakter underlättar för oss att manipulera den fysiska världen. På samma sätt som en cykel gör att en människa kan förflytta sig snabbare, hjälper texter och databaser oss att dokumentera, minnas och analysera oändliga mängder av information. Vår förmåga att bygga upp och aktivt använda det kulturella minnet ökar dramatiskt med sådana artefakter och teknologier.

Det intressanta i detta sammanhang är att också symboliska teknologier är kopplade till materialitet. Formler, tabeller, ritningar och andra tankeredskap går inte att utveckla om det inte finns materiella sammanhang i vilka de kan uttryckas och förädlas som tankestöd. En formel fordrar oftast att den finns nedtecknad på papper för att den ska kunna förstås och läras. Man behöver kunna betrakta den och tänka igenom vad den innebär. Också symboliska teknologier har en sociogenes, de förändras när nya material tas i bruk och när nya sätt att tänka etableras. Artefakter som används för att räkna är en illustration av detta intima förhållande mellan tänkande och material.

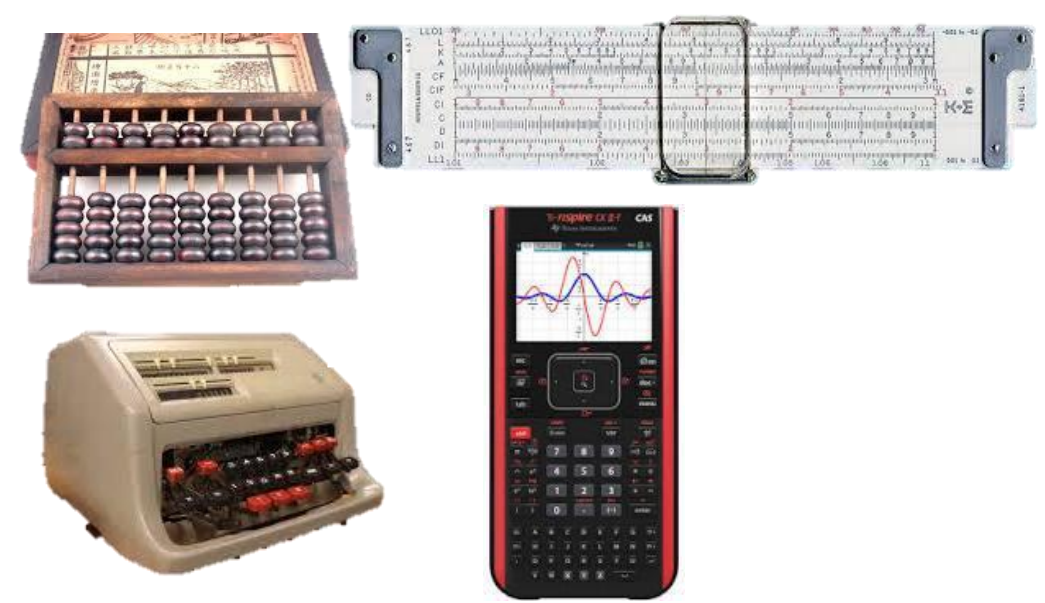

Figur 2. Räknare (abakus, räknesticka, mekanisk räknare och en modern grafisk kalkylator

I figur 2 visas några av den stora mängd tankestöd för räknande som uppfunnits genom historien. Abakusen, som funnits i olika varianter i många tusen år och i olika delar av världen, känns igen i våra kulramar som ännu finns i många hem och även i pedagogiska miljöer. Räknandet sker här genom att man flyttar kulor i specifika mönster. Den som är en erfaren brukare av abakus kan uppnå en stor skicklighet $i$ att utföra operationer med en förbluffande precision. Fingrar (kroppen) och räknandet (de intellektuella operationerna) fungerar i ett intimt 
samspel som efterhand blir alltmer automatiserat. Intressant är också att om man är mycket van användare, så behöver man inte ha tillgång till en fysisk abakus. Man har "internaliserat" (Vygotsky, 1986) redskapet till en mental variant som man använder med stor precision (Hatano, Miyake, \& Binks, 1977).

Digitaliseringen har inneburit en tilltagande abstraktion av materialiteten. I sådana redskap kan vi bygga in funktioner som vi inte förstår eller behöver förstå i alla delar. Det är just därför som gränssnittet är så viktigt för att göra dem brukbara för användaren. Men dom är alltjämt sociomateriella till sin karaktär och vi möter dem alltid i ett materiellt sammanhang. Även appen eller sökmotorn ingår i en materiell miljö. Vi lär oss hantera dem genom att först hantera de materiella aspekter vi möter, vi lär oss navigera och operera med dem. Därefter tar vi till oss dem som medierande redskap i en mer avancerad mening. Vi lär oss söka, lagra och bearbeta information i en mängd situationer. Dessa lärandebanor - learning trajectories - illustreras för övrigt tydligt när man observerar hur små barn interagerar med digitala plattor. De lär sig först att hantera dem som fysisk teknologi (öppna dem, logga in, skifta mellan olika appar/program och så vidare). Detta utgör en förutsättning för att man ska kunna utnyttja dem som stöd för mentala aktiviteter som att spela spel, rita och så småningom kommunicera med andra i tal och skrift.

\section{Lärande och sociomaterialitet}

Artefakter och teknologier är konsekvenser av och ett uttryck för människors förmåga att lära. Vi kan omsätta våra idéer och tankar i redskap som vi sedan använder och så småningom tar för givna. De blir transparenta för oss och vi har ibland svårt att föreställa oss hur vi skulle agera utan dem. Det som en gång var dramatiska uppfinningar, som glasögon, kylskåpet eller sökmotorn, blir självklara och en del av vad vi förlitar oss på. Vi integrerar dem i våra handlingar, och våra förmågor finns inte längre enbart i vår hjärna eller kropp, utan de är "distributed" mellan oss och artefakter. Det som är svårt eller omöjligt att göra med våra egna förmågor, som att multiplicera fyrsiffriga tal med två decimaler genom huvudräkning eller att bevara stora mängder information, blir möjligt om vi kan använda papper och penna, en räknare eller en digital resurs. Våra kognitiva förmågor gör det möjligt för oss att vända oss utåt, mot världen och ta hjälp. På så sätt förflyttas gränsen för våra förmågor hela tiden.

Beroendet av materialitet finns således även i relation till abstrakta förmågor, som att räkna, skriva, analysera, minnas och hantera symboler mer allmänt. I digitala artefakter byggs alltmer sofistikerade processer in som vi nyttjar och förlitar oss på i vardagen. Det är intressant att notera att när våra föreställningar om kunskap, lärande och mänskliga förmågor etablerades under antiken, så var det en miljö utan den rikedom på artefakter som vi är vana vid. Det tankeredskap som höll på att etablera sig under denna tid var skriften och texten som medium 
för kommunikation. Vid denna tid reagerade man mot texten ungefär som många nu reagerar på digitala teknologier som en del av våra kunskaper och färdigheter. I Platons dialog Faidros (1984, s. 275) beklagar sig Sokrates över hur läsande och skrivande fördärvade ungdomars minne. Han menar att "denna din uppfinning [skriften] skall skapa glömska i lärjungars själar, enär de ej skola komma att odla sitt minne" och genom att lita på texter kommer de att "hämta minne utifrån, från främmande tecken och ej från sitt eget inre." Genom att läsa, istället för att lära sig utantill, skulle minnet och intellektet snabbt försämras.

Vad vi ser i dessa diskussioner om kunskap, lärande och till och med om mänsklig intelligens är två olika föreställningar om mänskliga förmågor (Cole \& Derry, 2005). En som bygger på en stark åtskillnad mellan intellekt (teori) och bruk av artefakter (praktik), och där intellektet är överordnat bruket av sociomateriella resurser. Förmågor fastställs i denna föreställning genom intelligenstest, personlighetstest och papper-och-penna test, det vill säga utan kontakt med stora delar av de artefakter som vi har tillgång till i andra sammanhang. Undervisning sker i stor utsträckning genom träning av specifika mentala förmågor, och skapande och estetiska inslag har en svag ställning. Mot detta kan man ställa ett perspektiv som ser artefakter som "cognitive amplifiers" (Nickerson, 2005) och som resurser som förlänger och förstärker våra förmågor - praktiska, intellektuella, estetiska - långt bortom det vi kan åstadkomma utan dem. En kompetent brukare av en dator, ett mikroskop eller ett bokföringsprogram har förmågor som vida överstiger vad en person utan sådana resurser kan åstadkomma. Kunskaperna man har går inte att skilja från de artefakter man har vant sig vid att hantera.

Insikten om våra förmågors nära kopplingar till sociomateriella resurser ger en delvis annan syn på pedagogiska förlopp och på hur kunskaper reproduceras i samhället. Detta blir allt tydligare ju mer sofistikerade artefakter och teknologier blir. Vi lär genom att använda digitala och andra redskap i olika situationer. Lärandebanan går ofta från användning i olika sammanhang till förståelse på en mer generell nivå. Vi kan operera med avancerade artefakter i olika praktiker och lär oss så småningom vilka egenskaper de har och hur vi kan använda dem i olika sammanhang. En betoning av sociomaterialiteten som en förutsättning för vårt kunnande leder också till en ökad betoning av lärande som en kreativ, utvecklande och problemlösande process. Processen inriktas inte enbart på reproduktion av befintliga kunskaper, utan också på förmågan att nyttja kunskaper och sociomateriella resurser i vårt kulturella minne för att åstadkomma något. Lärande blir något performativt (Säljö, 2015), som består i att man kan använda befintliga resurser på produktiva sätt. I sådana aktiviteter överträder vi gränserna mellan teori och praktik, vi nyttjar både våra förmågor att tänka och analysera, och vänjer oss samtidigt vid att använda de artefakter och teknologier som är centrala för vårt kulturella minne. 
Kognition och materialitet är således intimt förbundna med och ömsesidigt beroende av varandra, de utgör varandras förutsättningar. Vi lär och förstår i stor utsträckning genom de sociomateriella redskap vi lär oss behärska oavsett om vi ska skriva, räkna, rita eller designa och skapa något. Teori, praktik och estetik är närvarande $\mathrm{i}$ allt bruk av artefakter i pedagogiska processer och i andra sammanhang, och våra kunskaper finns $\mathrm{i}$ betydande utsträckning $\mathrm{i}$ våra förmågor att använda artefakter på ändamålsenliga och innovativa sätt. Det som i dagligt tal benämns praktiska och estetiska ämnen är de fält där våra förmågor att sluta gapet mellan idé och artefakt kommer till uttryck, där vi kan visa hur kunskaper har flera sidor: begreppslig insikt och nyskapande i en sociomateriell värld.

\section{Referenser}

Bateson, G. (1972). Steps to an ecology of mind. New York, NY: Ballantyne.

Cole, M., \& Derry, J. (2005). We have met technology and it is us. I R. J. Sternberg \& D. D. Preiss (Red.), Intelligence and technology. The impact of tools on the nature and development of human abilities. (s. 209-227). Mahwah, NJ: Erlbaum.

Danziger, K. (1997). Naming the mind. How psychology found its language. London: Sage. https://doi.org/10.1037/0708-5591.38.1.43

Diez-Martín, F., Sánchez Yustos, P., Uribelarrea, D., Baquedano, E., Mark, D. F., Mabulla, A., Fraile, C., Duque, J., Díaz, I., Pérez-González, A., Yravedra, J., Egeland, C. P., Organista, E. \& Domínguez-Rodrigo, M. (2015). The origin of the acheulean: The 1.7 million-year-old site of FLK West, Olduvai Gorge (Tanzania). Scientific Reports, 5. https://doi.org/10.1038/srep17839

Donald, M. (2010). The exographic revolution: Neuropsychological sequelae. I L. Malafouris \& C. Renfrew (Red.), The cognitive life of things. Recasting the boundaries of mind (s. 71-80). Cambridge: The McDonald Institute for Archaelogical Resaerch, University of Cambridge.

Donald, M. (2018). The evolutionary origins of human cultural memory. I B. Wagoner (Red.), Handbook of culture and memory (s. 19-40). Oxford: Oxford University Press. https://doi.org/10.1093/oso/9780190230814.003.0002

Gärdenfors, P. \& Högberg, A. (2017). The archaeology of teaching and the evolution of Homo docens. Current Anthropology, 58(2), 188-208. https://doi.org/10.1086/691178

Harmand, S., Lewis, J. E., Feibel, C. S., Lepre, C. J., Prat, S., Lenoble, A. Boës, X., Quinn, R. L., Brenet, M., Arroyo, A., Taylor, N., Clément, S., Daver, G., Brugal, JP., Leakey, L., Mortlock, R. A., Wright, J. D., Lokorodi, S., Kirwa, C., Kent, D. V. \& Roche, H. (2015). 3.3-million-year-old stone tools from Lomekwi 3, West Turkana, Kenya. Nature, 521(7552), 310-315. https://doi.org/10.1038/nature14464

Harris, D. R. (Red.) (1996). The origins and spread of agriculture and pastoralism in Eurasia. London: UCL Books.

Hatano, G., Miyake, Y. \& Binks, M. G. (1977). Performance of expert abacus operators. Cognition, 5, 47-55. https://doi.org/10.1016/0010-0277(77)90016-6

Hutchins, E. (1995). How a cockpit remembers its speed. Cognitive Science, 19, 256-288. https://doi.org/10.1207/s15516709cog1903_1

Ihde, D. (1990). Technology and the lifeworld: From garden to earth. Bloomington, IN: Indiana University Press. 
Johansson, M. (2002). Slöjdpraktik i skolan-hand,tanke, kommunikation och andra medierande redskap. Göteborg: Acta Universitatis Gothoburgesis.

Kress, G., \& Selander, S. (2010). Design för lärande - ett multimodalt perspektiv. Stockholm: Norstedts.

Latour, B. (1999). Pandora's hope. An essay on the reality of science studies. Cambridge, MA: Harvard University Press.

Lave, J., \& Wenger, E. (1991). Situated learning: legitimate peripheral participation. Cambridge, MA: Cambridge University Press. https://doi.org/10.1017/CBO9780511815355

Lundgren, U. P. \& Säljö, R. (2020). Skolans tidiga historia och utveckling - från skrivarskola till folkskola. I: U. P. Lundgren, R. Säljö, \& C. Liberg (Eds.), Lärande, skola, bildning (s. 27-67). Stockholm: Natur och Kultur.

Malafouris, L. (2013). How things shape the mind. Cambridge, MA: MIT Press. https://doi.org/10.7551/mitpress/9476.001.0001

Nickerson, R. S. (2005). Technology and cognition amplification. I R. Sternberg \& D. Preiss (Red.), Intelligence and technology. The impact of tools on the nature and development of human abilities. (s. 3-27). Mahwah, NJ: Erlbaum.

Platon. (1984). Faidros. Lund: Doxa.

Pruetz, J. D., Bertolani,P., Boyer Ontl, K., Lindshield, S., Shelley, M. \& Wessling, E. G. (2015). New evidence on the tool-assisted hunting exhibited by chimpanzees (Pan troglodytes verus) in a savannah habitat at Fongoli, Sénégal. Royal Society Open Science, 2(140507). https://doi.org/10.1098/rsos.140507

Satel, S., \& Lilienfield, S. O. (2013). Brainwashed: The seductive appeal of mindless neuroscience. New York, NY: Basic Books.

Statens medieråd, S. (2019). Småungar och medier. Stockholm: Statens medieråd.

Säljö, R. (2015). Lärande - en introduktion till perspektiv och metaforer. Malmö: Gleerups.

Säljö, R. (Ed.) (2011). Lärande och minnande som social praktik. Stockholm: Norstedts.

Varela, F. J., Thompson, E., \& Rosch, E. (1991). The embodied mind: cognitive science and human experience. Cambridge, MA: MIT Press. https://doi.org/10.7551/mitpress/6730.001.0001

Wartofsky, M. (1979). Models. Representation and the scientific understanding. Dordrecht: Reidel. https://doi.org/10.1007/978-94-009-9357-0

Whiten, A., Goodall, J., McGrew, W. C., Nishida, T., Reynolds, V., Sugiyama, Y., Tutin, C. E. G., Wrangham, R. W. \& Boesch, C (1999). Cultures in chimpanzees. Nature, 399(6737), 682-685. https://doi.org/10.1038/21415

Vygotsky, L. S. (1986). Thought and language. Cambridge, MA: MIT Press.

Roger Säljö, fil dr och dr hon. causa mult., och professor/seniorforskare i pedagogisk psykologi vid Göteborgs universitet. Hans forskning rör frågor om lärande och utveckling, och särskilt frågor om samspelet mellan materialitet och kognitiva förmågor. Huvuddelen av detta intresse rör hur utvecklingen av symboliska teknologier (skrift, räknesystem, digitala teknologier etc.) förändrar människors sätt att kommunicera, bevara och få tillgång till information och kunskaper. 